\title{
PRELIMINARY OBSERVATIONS \\ ON THE FAMILY MORMYRIDAE \\ IN OYAN DAM LAKE \\ (NIGERIA)
}

\author{
Olaniyi Alaba OLOPADE * \\ * University of Port Harcourt, Department of Animal Science and Fisheries, Rivers State, Nigeria, \\ oaolopade@yahoo.com
}

KEYWORDS: Mormyridae, diversity, length-weight, condition factor, Oyan Lake.

\begin{abstract}
This study was carried out to investigate the abundance, distribution, diversity and condition factor of Mormyrids in Oyan Dam lake, Abeokuta North Local Government Area of Ogun State, Nigeria. The fish were sampled from the catches of the fishermen in Oyan Dam lake, which used gillnets of 30-80 mm laterally stretched mesh size. The fish were sampled monthly between February and September 2011, at two different sites (Imala and Ibaro). The results revealed that a total number of 100 fishes of six species belonging to the family Mormyridae were collected. Numerically, catches were dominated by Mormyrus rume (34\%), Hyperopisus bebe (30\%) and Petrocephalus bane (24\%). Together, these species comprised $88 \%$ of all collected individuals. Marcusenius ihuysi was rare and least in number representing $1 \%$ of the fish caught. The results showed that only four species were recorded in the dry season, namely Mormyrus rume, Hyperopisus bebe, Petrocephalus bane and Mormyrus deliciosus while five species were recorded in the wet season particularly in September. Mormyrus deliciosus, was not recorded in the wet season. In terms of body weight, the highest mean value was recorded for Mormyrus deliciosus (435.71 \pm 95.71$)$, followed by Mormyrus rume $(143.82 \pm 5.55)$ and Hyperopisus bebe $(123.5 \pm 5.26)$ while Petrocephalus bane was the least one $(95.00 \pm 8.56)$. The results also showed that the condition factor during the wet season (4.18) was higher than the condition factor of the dry season (3.51). Simpson's index was used to determine the species richness, while Shannon-Wiener's Index was used to evaluate species diversity; species evenness was equally evaluated using Pielou's Index. The indices of diversity included $(\mathrm{d})=0.31$ and $0.23, \mathrm{H}=1.18$ and 1.53 and $\mathrm{E}=0.851$ and 0.853 respectively for the two sites at Oyan Dam lake. The estimates from these indices indicated a low fish species composition and richness, also unevenness in the population of Mormyrids in Oyan Dam lake. Therefore, it will be advisable to regulate the activities of fishers in the water body to allow future increase in the abundance of this species.

RÉSUMÉ: Observations préliminaires de la famille des Mormyridés du lac de barrage d'Oyan (Nigeria).

Ce travail a eu pour but l'étude de l'abondance, de la distribution, de la diversité et de l'indice de Fulton des Mormyridés du lac de barrage d'Oyan, dans la Zone Gouvernementale Locale Nord Abeokuta de l'Etat d'Ogun, au Nigeria. Les poissons ont été échantillonnés à partir des captures des pêcheurs du lac d'Oyan qui utilisent des filets de pêche à la mèche de 30-80 mm. Les échantillons ont été collectés chaque mois de février à septembre 2011 dans
\end{abstract}


deux sites différents (Imala et Ibaro). Un nombre total de 100 poissons appartenant à 6 espèces de la famille de Mormyrides ont été collectés. De point de vue numérique, les captures ont été dominées par Mormyrus rume (34\%), Hyperopisus bebe (30\%) et Petrocephalus bane (24\%). Ces trois espèces constituent $88 \%$ de tous les individus collectés. Marcusenius ihuysi a été rare, comptant pour moins de $1 \%$ des poissons capturés. Les résultats ont montré que seulement quatre espèces ont été inventoriés durant la saison sèche: Mormyrus rume, Hyperopisus bebe, Petrocephalus bane et Mormyrus deliciosus; cinq espèces ont été récoltées durant la saison humide, surtout durant le mois de septembre. Mormyrus deliciosus n'a pas été pêché pendant toute la saison humide. En termes de poids, la plus grande valeur moyenne a été enregistrée pour Mormyrus deliciosus $(435,71 \pm 95,71)$, suivi par Mormyrus rume $(143,82 \pm$ $5,55)$ et Hyperopisus bebe $(123,5 \pm 5,26)$, alors que Petrocephalus bane a eu le plus petit poids moyen $(95,00 \pm 8,56)$. Les résultats ont aussi montré que durant la saison humide, l'indice de Fulton $(4,18)$ a été plus grand que celui calculé lors de la saison sèche $(3,51)$. L'indice de Simpson a été utilisé pour déterminer la richesse des espèces, alors que l'indice de ShannonWiener a été utilisé dans l'évaluation de la diversité des espèces; l'équitabilité des espèces a été calculée par l'indice de Pielou. Les indices de diversité ont compris $(\mathrm{d})=0,31$ et $0,23, \mathrm{H}=$ 1,18 et 1,53 et $\mathrm{E}=0,851$ et 0,853 respectivement, pour les deux sites du lac de barrage d'Oyan. Les estimations faites à partir de ces indices ont montré une composition spécifique et une richesse basses de l'ichtyofaune ainsi qu'un manque d'équitabilité des populations de Mormyridés dans le lac d'Oyan. Il est donc souhaitable de réglementer les activités de pêche dans ces lacs afin de permettre aux espèces de regagner leur abondance naturelle.

REZUMAT: Observaţii preliminare asupra familiei Mormyridae în lacul de acumulare Oyan (Nigeria).

Acest studiu a avut ca scop cercetarea faunei de Mormyridae din lacul de acumulare Oyan, situat in Zona Guvernamentală Locală Nord Abeokuta din statul Ogun, Nigeria, sub aspectul abundenței, distribuției, diversității și indicelui Fulton. Peștii au fost colectați din capturile efectuate de pescarii de pe lacul Oyan cu ajutorul plaselor de pescuit cu ochiuri de 30-80 mm. Eșantioanele au fost prelevate lunar din februarie în septembrie 2011, din două puncte diferite (Imala și Ibaro). S-au colectat în total 100 de exemplare aparținând la 6 specii din familia Mormyridae. Din punct de vedere al abundenței, capturile au fost dominate de Mormyrus rume (34\%), Hyperopisus bebe (30\%) și Petrocephalus bane (24\%). Aceste trei specii au format împreună $88 \%$ din indivizii colectați. Specia Marcusenius ihuysi a fost rară, cuprinzând mai puțin de $1 \%$ din peștii capturați. Rezultatele au demonstrat că în timpul sezonului uscat doar patru specii au fost capturate: Mormyrus rume, Hyperopisus bebe, Petrocephalus bane și Mormyrus deliciosus; în timpul sezonului umed au fost capturate 5 specii, mai ales în luna septembrie, lipsind în acest sezon Mormyrus deliciosus. Din punct de vedere al masei, valoarea medie cea mai mare a fost înregistrată pentru Mormyrus deliciosus (435,71 $\pm 95,71)$, urmată de Mormyrus rume $(143,82 \pm 5,55)$ și Hyperopisus bebe $(123,5 \pm$ $5,26)$ în timp ce Petrocephalus bane a avut greutatea medie cea mai mică $(95,00 \pm 8,56)$. Rezultatele au mai demonstrat că indicele Fulton pentru sezonul umed $(4,18)$ a fost mai mare ca cel pentru sezonul uscat $(3,51)$. S-au calculat indicii de biodiversitate Simpson și ShannonWiener precum și echitabilitatea Pielou. S-au obținut valorile $(\mathrm{d})=0,31$ și $0,23, \mathrm{H}=1,18$ și 1,53 și $\mathrm{E}=0,851$ și 0,853 pentru cele două situri de pe lacul Oyan. Estimările făcute pe baza valorilor acestor indici denotă o compoziție specifică și o diversitate scăzute, precum și o lipsă de echitabilitate a populațiilor de Mormyridae în lacul de acumulare Oyan. Se recomandă, deci, reglementarea activităților piscicole în acest acvatoriu în așa manieră încât să permită speciilor să își reconstruiască efectivele. 


\section{INTRODUCTION}

Nigeria is a country of vast and varied fish germ plasma resources distributed widely in various aquatic ecosystems. Fish stocks in Nigerian inland and marine waters are characterized by heterogeneity of many species which are of commercial importance. There are approximately 230 inland fish species (Ita, 1993) and 199 of brackish marine species (Tobor, 1965, 1968). Notable among the freshwater fish species in Nigeria are Tilapia, Clarias, Heterobranchus, Synodontis, Chrysichthys, Mormyrus, Lates, Gymnarchus, Alestes, Bagrus, Labeo, Heterotis spp. and many ornamental fish species.

Mormyrus is the genus of Mormyridae which was described by Linnaeus (1758). Mormyrids or elephant snout fishes are curious looking fish, highly variable in shapes of their head and the extent of their unpaired fins. They are recognized by the possession of upward pointing pectoral fins, narrow gill openings and a layer of muscle covering the opercula bone (Holden and Reed, 1972). In some species, the eyes are very small compared to the size of the fish. The fishes of this family are normally caught in the bottom net, an indication that they are bottom feeders (Adebisi, 1978).

With more than 200 species belonging to 20 genera, the Mormyridae Family is a modern radiation within the Osteoglossomorpha, an ancient lineage of teleost fishes in which most other living groups are species-poor (Bigorne, 1990). Mormyrids reach their highest diversity in the river systems of Central and West Africa and are often from the numerical point of view the most abundant fish in riverine habitats (Harder, 2000). Some form large schools near the bottom of pools; others are adapted for life in and near rapids (Roberts and Stewart, 1976) of smaller streams, marginal habitats, or swamps (LoweMcConnell, 1987). However, with the construction of dam and weirs on most rivers for irrigation, hydropower or flow management have provided an opportunity to see how freshwater fish adapt to lake type environments. Distributions and abundances of native species may be altered by the reservoir formation, including loss of species from the river system and threatening with extinction of endemic species (Wheeler and McDonald, 1986).

The Volta Lake area on the national territory of Ghana was studied by Petr (1967) both before and after the dam construction. Mormyrids underwent the most dramatic drop in population as a result of the lake formation, nearly disappearing from the fish catches in the southern part of Volta Lake (less than $2 \%$ of the biomass of total fish catches), and maintained themselves only in the northern part of the lake, where they had access to river feeding conditions. Before the construction of the dam, the Black Volta River (Ghana) mormyrids comprised over $65 \%$ of dry season catches (biomass). A similar decline in Mormyrids was noted for the Niger River after the creation of Kainji Lake in Nigeria (Blake, 1977). Orts (1967) highlight the fact that most mormyrids appear to have a lack of specialization for air breathing, they may thus be poorly adapted to living on deoxygenated lake bottoms. Since many mormyrids appear to feed exclusively upon bottom-dwelling insect larvae, this situation may make lacustrine environments unsuitable in many cases (Petr, 1967).

There is little specific information on diversity of the family Mormyridae in Nigeria particularly with reference to reservoirs ecosystem. In these general circumstances, this scientific study was carried out to investigate the abundance, distribution, diversity and condition of the Mormyridae Family and their contribution to species richness of Oyan Lake (Fig. 1). 


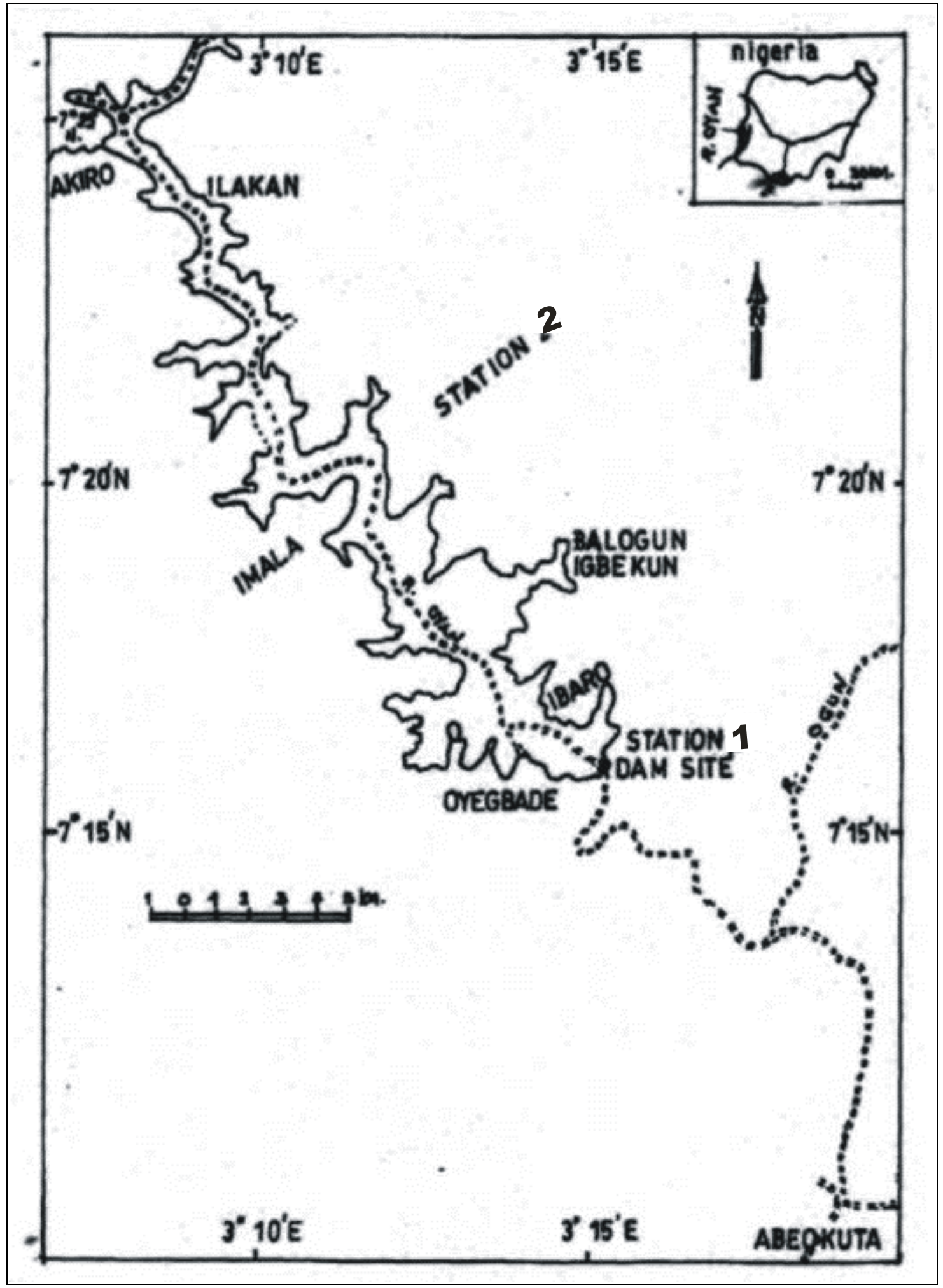

Figure 1: Map of the Oyan Lake with the sampling stations localization. 


\section{MATERIALS AND METHODS}

\section{Study area}

The Oyan River dam is located in Abeokuta North Local Government Area of Ogun State in the west of Nigeria, about $20 \mathrm{~km}$ north west of the state capital Abeokuta. The dam crosses the Oyan River, a tributary of the Ogun River. It was used primarily to supply raw water to Lagos and Abeokuta, but has also potential for use in irrigation and power generation. The dam is located on the latitude of $7^{\circ} 15^{\prime} \mathrm{N}$ and longitude $3^{\circ} 16^{\prime} \mathrm{E}$ at an elevation of $43.3 \mathrm{~m}$ above the sea level on the confluence of Oyan and Ofiki rivers, both tributaries of Ogun river some 20 kilometres north-west of Abeokuta, close to Badagry - Sokoto Highway (O-ORBDA 1998; Ofoezie et al., 1991). The lake is in the savannah region, with sparse trees and grasses and low soil fertility. It covers a total of 4,000 hectares and has a catchment area of $9,000 \mathrm{~km}^{2}$. The dam has a crest length of $1,044 \mathrm{~m}$, a height of $30.4 \mathrm{~m}$ and a maximum storage capacity of 270 million $\mathrm{m}^{3}$ (Ofoezie and Asaolu, 1997). The dam and lake were designed to supply with raw water Lagos and Abeokuta, and to support the 3,000 hectare Lower Ogun Irrigation Project. Three turbines of 3 megawatts each were installed in 1983, but until 2007 have not been used (Ikenweinwe et al., 2007).

\section{Fish sampling}

The fish samples were collected from the catches of the fishermen from two stations in Oyan Lake; they were caught by gillnets of 30-80 mm laterally stretched mesh size. The fish were collected monthly at the two different sites (Imala/site 1 and Ibaro/site 2) from March to September, 2011 to determine the distribution pattern and abundance of momyrids in the lake.

Identification of the various species of mormyrids was done using Daget (1954) and Holden and Reed (1972). The confirmation of the sampled/identified species was carried out based on their color and meristic characters. Standard length (SL), total length (TL) and weight $(\mathrm{W})$ of the specimens were measured to the nearest $0.1 \mathrm{~cm}$ and $0.1 \mathrm{~g}$ respectively.

\section{Analysis of data}

The ecological indexes used to describe the Mormyrids diversity in Oyan Lake are:

a. The relative species abundance $\%=(\mathrm{n} / \mathrm{N}) \times 100$, which refers to the relative representativenes of a species, was determined by dividing the number of species (n) from each catch by the total number of species $(\mathrm{N})$ from the total catch recorded $\mathrm{W}=\mathrm{a} \mathrm{L}^{\mathrm{b}}$

b. The length-weight relationship (LWR) was estimated by using the equation

Where $\mathrm{W}=$ Weight $(\mathrm{g})$

$\mathrm{L}=$ Standard length $(\mathrm{cm})$

$\mathrm{a}=$ Constant

$\mathrm{b}=$ Growth exponent.

c. The equation will be linearised by a logarithmic transformation to give:

$\log W=\log a+b \log L$

d. The value of the compiled growth exponent that will be used to calculate the condition factor, $\mathrm{K}$

$\mathrm{K}=100 \mathrm{~W}$

$\mathrm{L}^{\mathrm{b}}$

Where $\mathrm{K}=$ Condition Factor

$\mathrm{W}=$ Total body weight $(\mathrm{g})$ 
$\mathrm{L}=$ Standard Length $(\mathrm{cm})$

$\mathrm{b}=$ Growth exponent

Simpson's index $(\mathrm{d})=\sum \mathrm{n}(\mathrm{n}-1)$

$\mathrm{N}(\mathrm{N}-1)$

e. The Simpson's index (d) was used to evaluate species richness

f. Shannon - Wiener's Index (H') of species diversity (Shannon and Wiener, 1963) $\mathrm{H}^{\prime}=-\sum \mathrm{P}_{\mathrm{i}} \ln \mathrm{P}_{\mathrm{i}}$

eqn (5)

Where $P_{i}=$ The proportion of the total number of individuals occurring in species

$\mathrm{i}, \mathrm{n}$ is the number of individuals of each species and

$\mathrm{N}$ is the total number of individuals.

The Shannon - Wiener's Index (H') were used to evaluate species diversity.

$\mathrm{J}=\mathrm{H}^{\prime}$

g. Pielou's Index (J) for species evenness (Pielou, 1969),

$\ln \mathrm{S}$ eqn (6)

Where $\mathrm{H}^{\prime}$ is the species diversity index and $\mathrm{S}$ is the number of species

\section{RESULTS}

Composition of the family Mormyridae in Oyan Lake

A total number of 100 fishes of six species belonging to the family Mormyridae were collected. Numerically, catches were dominated by Mormyrus rume (34\%), Hyperopisus bebe (30\%) and Petrocephalus bane (24\%). Together, these species comprised $88 \%$ of all individuals collected. Marcusenius ihuysi was the least in number accounting for $1 \%$ of caught fish. Mormyrops deliciosus and Marcusenius ihuysi were not recorded in the site 1 (Tab. 1).

Table 1: Percentage composition of Mormyrids in Oyan Lake; number (percentage) of fish caught from the sites.

\begin{tabular}{|l|c|c|c|}
\hline Species & $\mathrm{S}_{1}$ & $\mathrm{~S}_{2}$ & Sum total number (\%) of fish caught \\
\hline $\begin{array}{l}\text { Mormyrus } \\
\text { rume }\end{array}$ & 16 & 18 & 34 \\
\hline $\begin{array}{l}\text { Hyperopisus } \\
\text { bebe }\end{array}$ & 16 & 14 & 30 \\
\hline $\begin{array}{l}\text { Petrocephalus } \\
\text { bane }\end{array}$ & 16 & 8 & 7 \\
\hline $\begin{array}{l}\text { Mormyrops } \\
\text { deliciosus }\end{array}$ & 0 & 7 & 4 \\
\hline $\begin{array}{l}\text { Marcusenius } \\
\text { psittacus }\end{array}$ & 1 & 3 & 7 \\
\hline
\end{tabular}

Seasonal distribution of the family Mormyridae species in Oyan Lake

The results of the seasonal distribution of the family Mormyridae in Oyan Lake are presented in table number 2 . 
Table 2: Summary of Relative Species abundance and seasonal variation of Mormyrids in Oyan Dam, Nigeria.

\begin{tabular}{|c|c|c|c|c|c|c|c|c|}
\hline & 201 & dry se & & \multicolumn{5}{|c|}{2011 (wet season) } \\
\hline Species & March & April & May & (Total\%) & July & August & September & (Total\%) \\
\hline $\begin{array}{l}\text { Mormyrus } \\
\text { rume }\end{array}$ & 3 & 10 & 6 & 19 (39.6) & 3 & 6 & 4 & $\begin{array}{c}15 \\
(35.7) \\
\end{array}$ \\
\hline $\begin{array}{c}\text { Hyperopisus } \\
\text { bebe }\end{array}$ & 3 & 9 & 5 & $17(35.4)$ & 4 & 5 & 6 & $\begin{array}{c}13 \\
(30.9) \\
\end{array}$ \\
\hline $\begin{array}{c}\text { Petrocephalus } \\
\text { bane }\end{array}$ & 4 & 7 & 4 & $15(31.3)$ & 3 & 2 & 4 & $9(21.4)$ \\
\hline $\begin{array}{c}\text { Mormyrops } \\
\text { deliciosus }\end{array}$ & 4 & 1 & 2 & $7(14.6)$ & - & - & - & $-(0)$ \\
\hline $\begin{array}{l}\text { Marcusenius } \\
\text { psittacus }\end{array}$ & - & - & - & $-(0)$ & 3 & 1 & - & $4(9.5)$ \\
\hline $\begin{array}{c}\text { Marcusenius } \\
\text { ihuysi }\end{array}$ & - & - & - & $-(0)$ & 1 & - & - & $1(2.4)$ \\
\hline Total & & & & 48 & & & & 42 \\
\hline
\end{tabular}

Only four species were recorded in the dry season namely Mormyrus rume, Hyperopisus bebe, Petrocephalus bane and Mormyrus deliciosus while five species were recorded in the wet season, particularly in September, Mormyrus deliciosus was not recorded in the wet season.

The relative abundance decreased with the increase in water level, (Tab. 2).

The dominant species during the dry season were Mormyrus rume (39.6\%), Hyperopisus bebe (35.4\%) and Petrocephalus bane (31.5\%). Similar results were recorded during the wet season with Mormyrus rume (35.7\%), Hyperopisus bebe (30.9\%) and Petrocephalus bane (21.4\%) species which dominated the sampled fish. Marcusenius psittacus (0\%) and Marcusenius ihuysi (0\%) were not recorded during the dry season. Likewise, Mormyrops deliciosus species was conspicuously absent during the wet season.

\section{Size of Mormyridae in Oyan dam}

In terms of fish body weight, the highest mean value was recorded for Mormyrus deliciosus $(435.71 \pm 95.71)$, followed by Mormyrus rume (143.82 \pm 5.55$)$ and Hyperopisus bebe $(123.5 \pm 5.26)$, while Petrocephalus bane was the last $(95.00 \pm 8.56)$. In terms of length, the highest mean value was recorded for Mormyrus deliciosus $(35.89 \pm 1.67)$, followed by Mormyrus rume $(22.85 \pm 0.61)$ and Hyperopisus bebe $(22.47 \pm 0.43)$, while the last value of $17.2 \pm 0.00$ was recorded on Marcusenius ihuysi (Tab. 3). 
Table 3: Sizes of Mormyrids species in Oyan Dam. Body weight (g)

\begin{tabular}{|l|c|c|l|l|l|l|}
\hline Species & Min & Max & Mean \pm SE & Min & Max & Mean \pm SE \\
\hline $\begin{array}{l}\text { Hyperopisus } \\
\text { bebe }\end{array}$ & 80 & 210 & $123.5 \pm 5.26$ & 18 & 28 & $22.47 \pm 0.43$ \\
\hline $\begin{array}{l}\text { Mormyrus } \\
\text { rume }\end{array}$ & 100 & 230 & $143.82 \pm 5.55$ & 17.4 & 31.7 & $22.85 \pm 0.61$ \\
\hline $\begin{array}{l}\text { Petrocephalus } \\
\text { bane }\end{array}$ & 60 & 220 & $95.00 \pm 8.56$ & 14 & 30.0 & $19.01 \pm 0.74$ \\
\hline $\begin{array}{l}\text { Mormyrops } \\
\text { deliciosus }\end{array}$ & 140 & 800 & $435.71 \pm 95.71$ & 26.8 & 40 & $35.89 \pm 1.67$ \\
\hline $\begin{array}{l}\text { Marcusenius } \\
\text { psittacus }\end{array}$ & 100 & 120 & $111.25 \pm 4.27$ & 16.8 & 18.6 & $17.65 \pm 0.42$ \\
\hline $\begin{array}{l}\text { Marcusenius } \\
\text { ihuysi }\end{array}$ & 110 & 110 & $110 \pm 0.00$ & 17.2 & 17.2 & $17.2 \pm 0.00$ \\
\hline
\end{tabular}

\section{Diversity index of family Mormyridae in Oyan Lake}

Table 4 shows Simpson's index for the site 1 which was 0.31 and 0.23 for the site 2 . This suggests the fact that the species were similar. However, using Margalef's species index (d), the species richness of the site 1 was 0.69 and 0.77 for the site 2. Simpson's reciprocal index was 3.27 in the site 1 and 4.31 in the site 2 while the Shannon's index (H) for site 1 was 1.18 and for the site 2 it was 1.53 . Pielou's index $(\mathrm{J})$ for species evenness was 0.851 for site 1 and 0.853 for site 2 . The value in the site $1(0.851)$ was higher than in the site 2 .

Table 4: Diversity Index and Species richness of Mormyrids in Oyan Lake; $\mathrm{N}=$ total number of organisms of all species found, $n=$ number of individuals of a particular species, $n !=$ total number of species present in sampled population, $\mathrm{k}=$ number of unique species of which only one organism was found in sampled population, $D=$ diversity index, $S=$ species richness. $i=$ an index number for each species present in a sample, $\mathrm{pi}=\mathrm{ni} / \mathrm{N}=$ the number of individuals within a species (ni) divided by the total number of individuals $(\mathrm{N})$ present in the entire sample, $\ln =$ natural $\log . \sum=$ sum the values for each species.

\begin{tabular}{|l|c|c|}
\hline Diversity indexes & Site 1 (Imala) & Site 2 (Ibaro) \\
\hline Number of species & 4 & 6 \\
\hline Number of individuals & 49 & 51 \\
\hline Simpson's index d $=\sum \frac{\mathrm{n}(\mathrm{n}-1)}{\mathrm{N}(\mathrm{N}-1)}$ & 0.31 & 0.23 \\
\hline Margalef's index of diversity (D) $=(\mathrm{S}-1)$ & 0.69 & 0.77 \\
\hline Simpson's reciprocal index $=(1 / \mathrm{d})$ & 3.27 & 4.31 \\
\hline Shannon-Weiner index H' $=-\sum p i \ln p i$ & 1.18 & 1.53 \\
\hline Pielou's Index $(\mathrm{J})=\mathrm{H}^{\prime} / \ln \mathrm{S}$ & 0.851 & 0.853 \\
\hline
\end{tabular}




\section{Monthly condition factors of Mormyrids species in Oyan Lake}

The condition factor of six species of Mormyrids are presented in table 5 in wet and dry season with the minimum and maximum value of 0.44 (Mormyrops deliciosus) and 2.19 (Marcusenius psittacus). The mean value of the condition factor ranged from 0.97 to 1.65 . The condition factor of Mormyrus rume for both seasons ranged from 0.14 to 1.54, in the month of May having the lowest and August having the highest value, Hyperopisus bebe ranged from 0.94 to 1.21 , Petrocephalus bane recorded the condition factor of 1.33 to 1.72 , Mormyrops deliciosus ranged from 0.49 to 1.09 , while Marcusenius psittacus ranged from 1.96 to 2.19. The only species recorded in August had a condition factor of 2.16 (Marcusenius ihuysi).

Table 5: Summary of the Monthly Condition Factor of Mormyrids in Oyan Lake.

\begin{tabular}{|l|c|c|c|c|c|c|}
\hline Species & March & April & May & July & August & September \\
\hline $\begin{array}{l}\text { Mormyrus } \\
\text { rume }\end{array}$ & 0.81 & 1.27 & 0.14 & 1.49 & 1.54 & 0.63 \\
\hline $\begin{array}{l}\text { Hyperopisus } \\
\text { bebe }\end{array}$ & 1.07 & 0.94 & 1.12 & 1.02 & 1.21 & 0.97 \\
\hline $\begin{array}{l}\text { Petrocephalus } \\
\text { bane }\end{array}$ & 1.72 & 1.46 & 1.45 & 1.55 & 1.41 & 1.33 \\
\hline $\begin{array}{l}\text { Mormyrops } \\
\text { deliciosus }\end{array}$ & 1.09 & 0.44 & 0.59 & - & - & - \\
\hline $\begin{array}{l}\text { Marcusenius } \\
\text { psittacus }\end{array}$ & - & - & - & 2.19 & 1.96 & - \\
\hline $\begin{array}{l}\text { Marcusenius } \\
\text { ihuysi }\end{array}$ & - & - & - & - & 2.16 & - \\
\hline Mean & 1.17 & 1.02 & 1.32 & 1.56 & 1.65 & 0.97 \\
\hline Total mean & & 3.51 & & & 4.18 & \\
\hline
\end{tabular}

The monthly condition factors of all species studied is shown in table number 5 , while the graphical representation of the monthly condition factor for each species is presented in figures number 2 to 5 . There were differences in the condition factors for the combined fish species and the monthly factor for each fish species studied. The result revealed that the condition factor during wet season (4.18) was higher than the condition factor of the dry season (3.51).

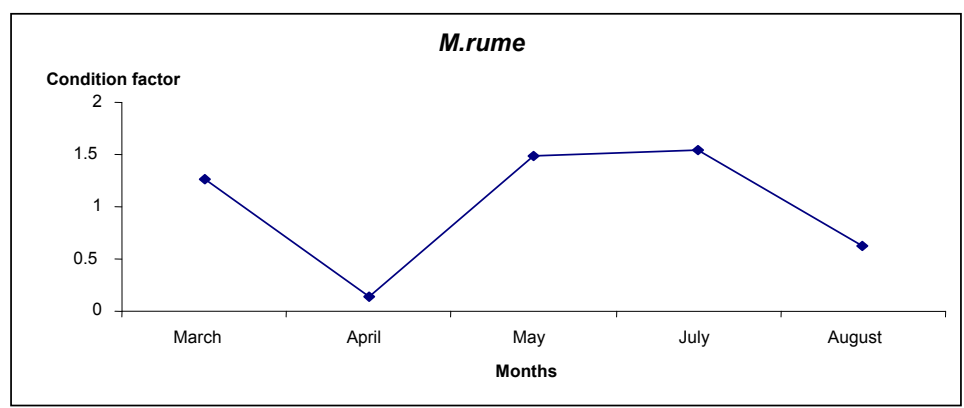

Figure 2: Mean condition factor for Mormyrus rume. 


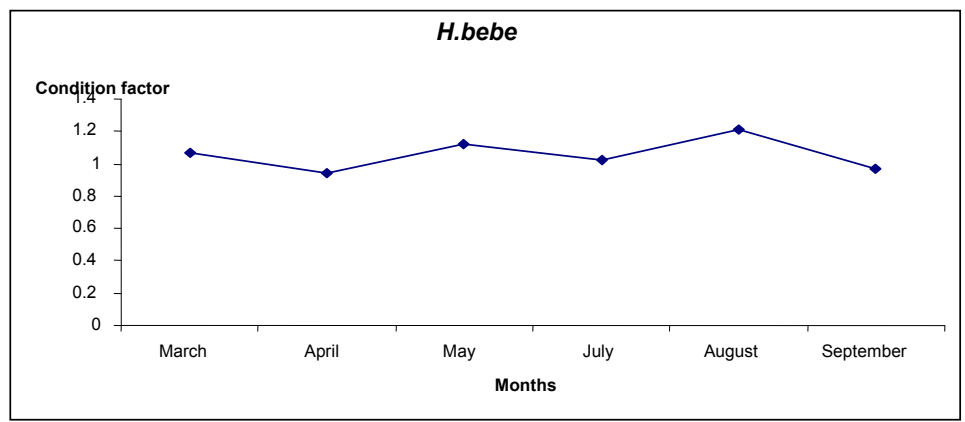

Figure 3: Mean condition factor for Hyperopisus bebe.

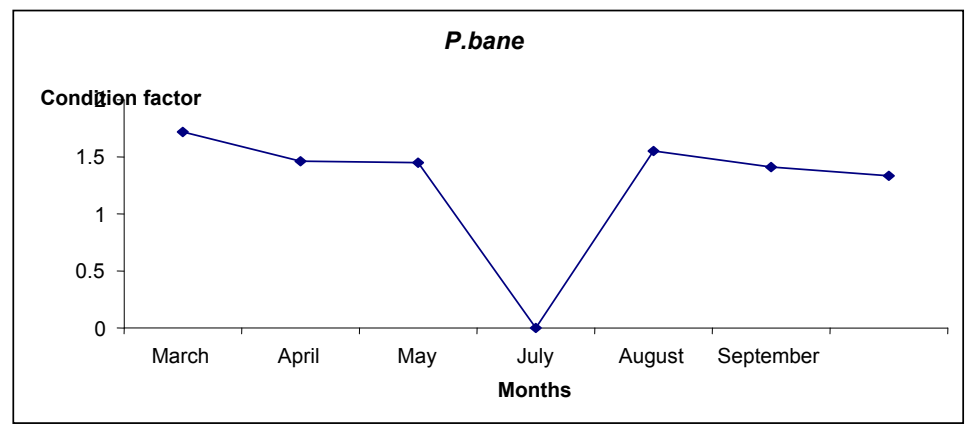

Figure 4: Mean condition factor for Petrocephalus bane.

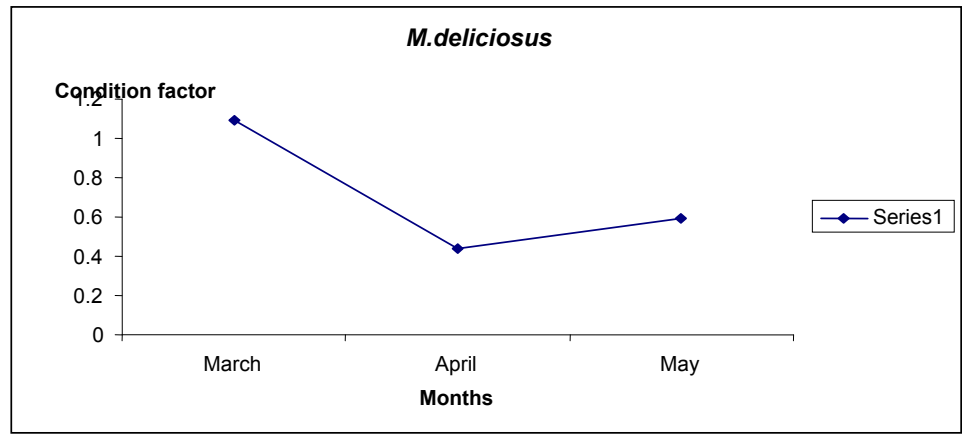

Figure 5: Mean condition factor for Mormyrops deliciosus.

The figures 6-13 show the graphical representations of the relationship between standard length and body weight and between condition factor and standard length. 


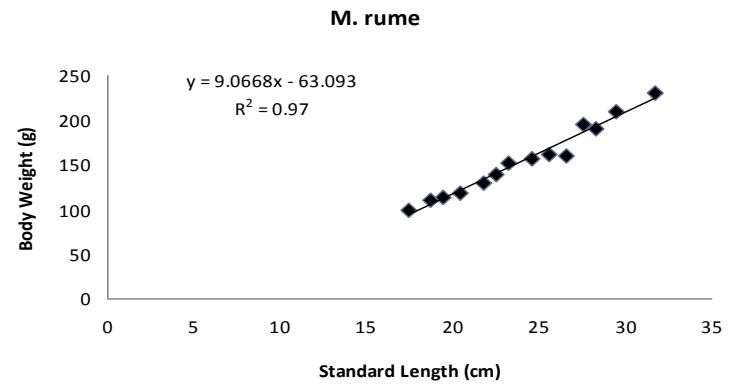

Figure 6: The graphical representation of the relationship between standard length and body weight of Mormyrus rume.

A straight-line relationship was shown suggesting that with an increase in the size of the fish there is a corresponding increase in the condition factor. The correlation coefficient $\mathrm{R}^{2}$ was high (0.92).

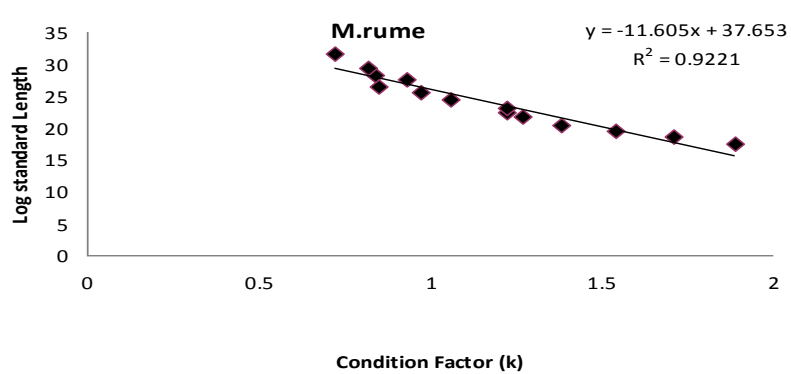

Figure 7: Shows the relationship between the condition factor and standard length of Mormyrus rume.

There is a negative relationship between the condition factor and the standard length.

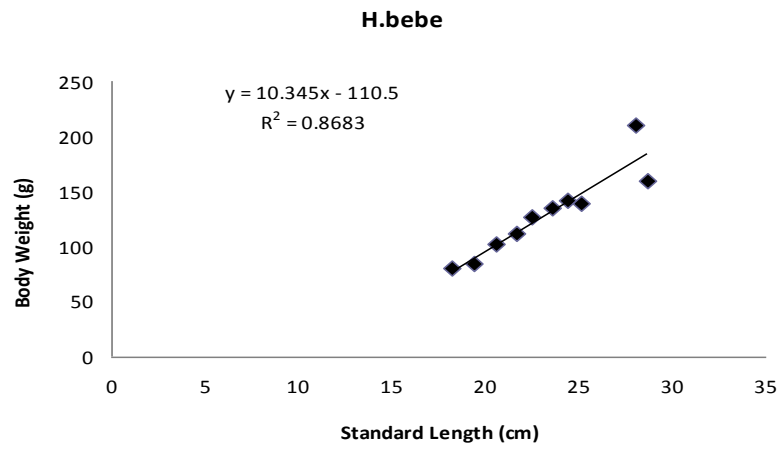

Figure 8: Shows the graphical representation of the relationship between the standard length and the body weight of Hyperopisus bebe. 
H.bebe

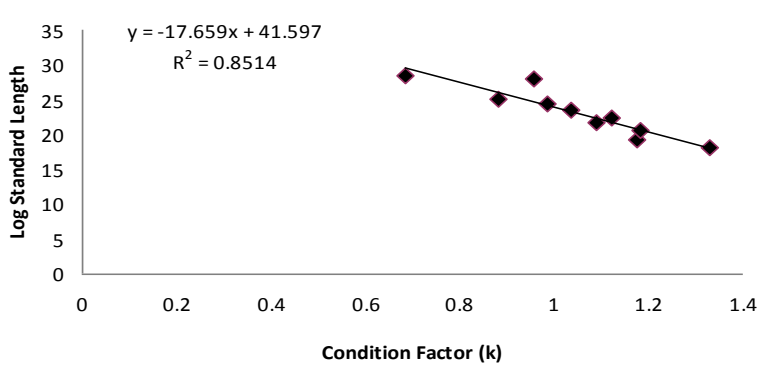

Figure 9: Shows the relationship between the condition factor and the standard length of Hyperopisus bebe.

This shows that the condition factor has no relationship with the standard length, $\mathrm{R}^{2}=$ 0.85 .

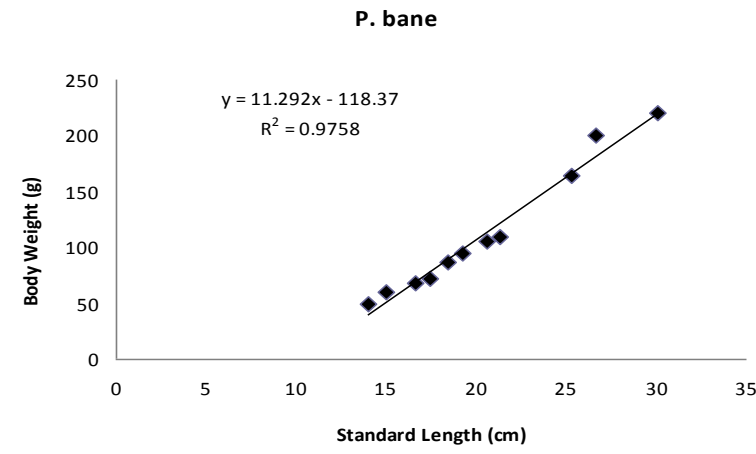

Figure 10: Shows the graphical representation of the relationship between the standard length and body weight of Petrocephalus bane.

The length of the fish maintains a steady relationship with the weight, for instance, an increase in length is related to an increase in the weight of the fish. The correlation coefficient $\mathrm{R}^{2}$ was 0.97 .

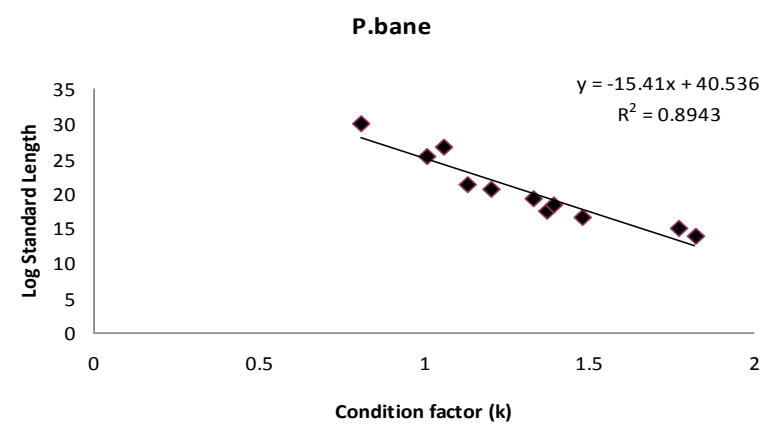

Figure 11: Shows the relationship between the condition factor and the standard length of Petrocephalus bane. 
As the length of the fish increases, the condition factor also increases negatively.

M.deliciosus

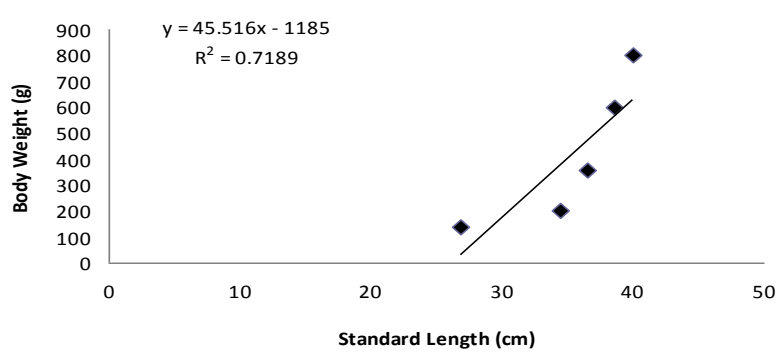

Figure 12: Shows the graphical representation of the relationship between the standard length and the body weight of Mormyrops deliciosus.

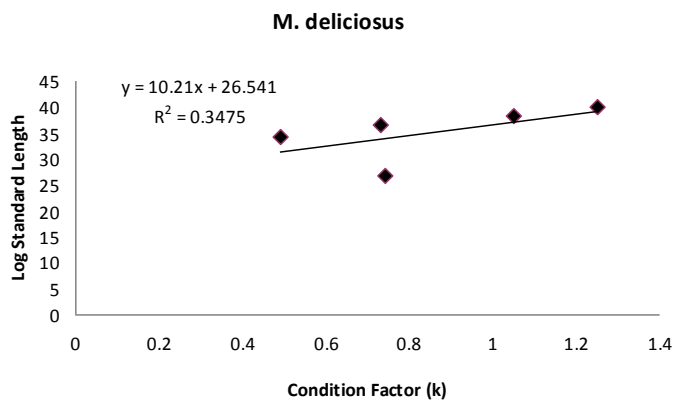

Figure 13: The relationship between the condition factor and standard length of Mormyrops deiciosus.

No relationship exists between the condition factor and the standard length of the fish below $30 \mathrm{~cm}$, but as the condition factor increases, a linear relationship was found.

\section{DISCUSSION}

Fish composition and diversity

A total of 29 mormyrid species have been described in the Nigerian freshwaters (Adesulu and Sydenham, 2007). This study revealed 6 species belonging to the family Mormyridae. The species composition was lower than the result of another study who revealed 8 species in the same water body (Ita, 1993). The limited number of the Mormyrids obtained during the sampling period could primarily be due to the factors related to the fishing gear deployment. According to Holden and Reed (1972), the majority of species have slender bodies and spines and they are difficult to catch with most normal types of fishing gears and, therefore, they make up only a small part of the commercial catches. Among the 6 species of fish in this study, Mormyrus rume was the most dominant. Olopade (2010) also recorded Mormyrus rume as the most abundant species of the family Mormyridae in Oyan Lake. The mormyrids fish, being a primitive taxonomic group, appears to have speciated primarily in rivers, not in lakes (Lowe-Mc Connell, 1969), this account for rear occurrence of Marcusenius ihuysi in the lake. Most Mormyrids appears to lack speciation for air breathing (Orts, 1967), they may thus be poorly adapted to living on deoxygenated lake bottoms. Since many Mormyrids appear to feed exclusively upon bottom-dwelling insect larvae, this situation may make lacustrine environments unsuitable in many cases (Petr, 1967). 
More species were recorded in site 2 than in site 1, in the Volta Lake and Kainji Lake, Mormyrids appear to be restricted to the extensive reed beds on the lake shores (Petr, 1967; Blake, 1977).

The result of seasonal caught composition of the family Mormyridae shows a relatively higher catch in the wet season than in the dry season. This could be attributed to spawning migratory behavior of mormyrids during the raining season. Rainy season spawning migrations from river mouths to upriver breeding habitats have been reported for some taxa (Daget, 1957; Blake, 1977). Marcusenius psittacus and Marcusenius ihuysi were not recorded in the dry season, but were recorded in the rainy season; indications are that the migratory fish are abundant during the rainy season, not necessarily for reproduction, but in response to changing environmental conditions, particularly temperature, and the movements and abundant of food organisms (Moyle and Cech, 1988).

The estimate of the diversity index (Tab. 4) shows a relative higher value for the downstream region than for the upstream region. This could be attributed to the physiochemical characteristics of the water. Other factors that could influence diversity include food availability and human influence (Fagade, 1983). In the absence of a pre-impoundment study in the Oyan Lake area, it was not possible to determine whether the fish fauna is depleted or not. Kartha (1987) pointed out that during the change of the lotic to lacustrine environment the fish diversity decreases.

In fish, the factor of condition $(\mathrm{K})$ reflects, through its variations, information on the physiological state of the fish in relation to its welfare (Le Cren, 1951). The range of the condition factor values fall below 2.9 to 4.8 , documented for optimum living condition for a fresh body weight (Begenal and Teseh, 1978). The values obtained from the study showed that all species studied were in good condition. Gayando and Pauly (1997) reported that certain factors often affect the well-being of a fish. Also, condition factors vary according to seasons and are influenced by environmental conditions. The results revealed that most of the lengthweight relationship of the species showed a linear graph. There was a significant correlation between body weight and standard length of species. This study showed an increase in length resulted in corresponding increase in weight. Length-weight relationships give information on the condition and growth patterns of fish (Bagenal and Tesch, 1978).

\section{CONCLUSIONS}

A total of six species belonging to the family of mormyrids was observed during the investigation. In the wet season five species were recorded, while only four species were recorded in the dry season. The result also revealed that the condition factor during the wet season was higher than in the dry season. The following species of mormyrids, Mormyrus rume, Hyperopisus bebe, Petrocephalus bane and Mormyrops deliciosus showed a linear relationship in terms of length-weight relationship. Based on the outcome of this study, it will be advisable that the dam should be replenished with other species of Mormyridae to allow future increasing in abundance and regulatory measures should be enforced particularly in the rainy season which coincides with the breeding season for sustainable fishery in Oyan Dam lake. 


\section{REFERENCES}

1. Adebisi A. M., 1978 - Analsis of stomach contents of Piscivororous fishes of the Upper Ogun River in Nigeria, Hydrobiologia, 79, 167-177.

2. Adesulu E. A. and Sydenham D. H. J., 2007 - The Freshwater Fishes and Fisheries of Nigeria, Macmillan Nigeria Publishers Ltd., Nigeria, 391.

3. Bagenal T. B. and Tesch F. W., 1978 - Methods of assessment of fish production in freshwater, 3rd edition, Oxford, Blackwell, 352.

4. Bazigos G. P., 1972 - The Design of Fisheries Statistical Surveys Inland Water, FAO Fish Technical Papers, 133, 120.

5. Bigorne R., 1990 - Mormyridae, in: Lévesque C., Paugy D. and Teugels G. G. (eds), Faune des poissons d'eaux saumatres d'Afrique de l'Quest, Tome 1, Faune Trop, 28 Musec Royal de l'Afrique Centrale Tervuren and ORSTOM, Paris, 645.

6. Blake B. F., 1977 - Aspects of the reproductive biology of Hippopotamyrus pictus from Lake Kainji West Africa with notes on four other mormyrid species, Fish Biology, 11, 437-445.

7. Daget J., 1991 - Chromidotilapia, in: Check-list of the freshwater fishes of Africa (CLOFFA) (eds) Daget J., Gosse J., Teugels J. P., and Thys van Audenaerde D. F. E., MRAC, Tervuren, and ORSTOM, Paris, 4, 47-50.

8. Fagade D. O., 1983 - The Biology of Chromodotilapia guntheri from a Small Lake, Archive Hydrobiology, 97, 60-72.

9. Gayando F. C. and Pauly D., 1997 - FAO ICLARM stock assessment tools FISAT: References Manual, FAO Computerized Information Series (Fisheries), 8, 262.

10. Harder W., 2000 - The Mormyridae and other Osteoglossomorpha, (CD-ROM), World Biodiversity Database, CD-ROM Series 2000, New York: Springer Verlag, ETI-UNESCO.

11. Holden M. J. and Reed W., 1972 - West African Freshwater Fish, Longman Group Ltd., London, 68.

12. Ikenweirwe N. B., Otubusin S. O. and Oyatogun M. O. O., 2007 - Fisheries of Oyan Lake, South West Nigeria and Potential for Ecotourism Development, European Journal of Scientific Research, 16, 3 .

13. Ita E. O., 1993 - Inland Fisheries Resources of Nigeria, FAO, CIFA Occasional Paper No. 20, Rome Italy, FAO, 120.

14. Kartha K. N., 1987 - Studies on experimental trawl fishing in Gandhisagar reservoir Mandsur, M. P. India, Ph. D thesis, Vikram University, Ujain India.

15. Le Cren E. D., 1951 - The length-weight relationship and seasonal cycle in gonad weight and condition in the Perca fluviatilis, Journal of animal Ecology, 20(2), 201-219.

16. Lek S. and Lek S., 1978 - Etude de quelques especes de petits Mormyridae du bassin du Lac Tchad, I, Observations sur Ia repartition et ecologie, Cah. O.R.S. T.O.M. Ser. Hydrobiologia, 12, 225-236.

17. Linnaeus C., 1758 - Systema Nature per Regna Tria Naturae secundum Classes, Ordinus, Genera, Species cum Characteribus, Differentiis Synonymis, Locis., 10th ed., 1, Holmiae Salvii, 824 .

18. Lowe-McConnell R. H., 1969 - Speciation in tropical freshwater fishes, Biological Linnean Society, 1, 51-75.

19. Moyle P. B. and Cech J. J. Jr., 1988 - Fish: An Introduction to Ichthyology 2nd edn., Hall and Cliffs (eds), 559

20. Ofoezie I. E. and Asaolu S. O., 1997 - Water level regulation and control of schistosomiasis transmission: a case study in Oyan Reservoir, Ogun State, Nigeria, Bulletin of the World Health Organization, 75(5), 435-441.

21. Ogun Osun River Basin Development Authority, 1997 - Brief on the activities of OORBD-A (1977-1996), OORBD-A Flyer March 1997, Ogun-Osun River Basin Development Authority 1998 (O-ORBDA), What it is, what it does, how it works, O-ORBDA, 5. 
22. Olopade O. A., 2010 - Observations of fishing methods in Oyan Lake, African Journal of Livestock Extension, 8, 35-39.

23. Orts S., 1967 - Contribution a l'anatomie coparee et la systematique des mormyrides, Memuse Academie Royale des Sciences Outremer, 17, 1-90.

24. Petr T., 1967 - Fish population changes in the Volta Lake in Ghana during its first sixteen months, Hydrobiology, 30, 193-220.

25. Pielou E. C., 1969 - An Introduction to Mathematical Ecology, Jonn Wiley \& Sons, New York, 288.

26. Robert T. R. and Stewart D. J., 1976 - An ecological and systematic survey of fishes in the rapids of the Lower Zaire or Congo River, Bulletin of the Museum of Comparative Zoology, 147, 239-317.

27. Shannon C. E. and Wiener W., 1963 - The Mathematical Theory of Communication, U. Illinois, Urbana, Illinois, 117.

28. Sullivan J. P., Lavoué S. and Hopkins C. D., 2000 - Molecular systematics of the African electric fishes (Mormyroidea, Teleostei) and a model for the evolution of their electric organs, Journal of Experimental Biology, 203, 665-683.

29. Swingle H. S., 1950 - Relationships and Dynamics of Balanced and Unbalanced Fish Populations, Alabama Polytechnic Institution Agricultural Experimental Station Bulletin, 244, 74.

30. Tang Y. A., 1970 - Evaluation of Balanced between Fishes and Available Fish Foods in Multispecies Fish Culture Ponds in Taiwan, Transactions of American Fisgeries Society, 99, 708718.

31. Tobor J. G., 1965 - Identification notes, fishes of the Nigerian trawling grounds, Federal Fisheries Occasional Paper, 9.

32. Tobor J. G., 1968 - Checklist of the less common marine fish of Nigeria, caught in Lagos trawling grounds, Federal Fisheries Occasional Paper, 10.

33. Turner J. L., 1970 - Fish population of newly impounded Kainji Lake in Nigeria, Journal of West African Science Association, 1(1), 49-58.

34. Wheeler W. B. and McDonald M. J., 1986 - TVA and the Tellico Dam, 1936-1979: A bureaucratic crisis in post-industrial America, Knoxville, TN, University of Tennessee Press. 